Final Examination, July. 1905.-P. D. Sullivan.

D.P.H.-J. F. Stewart, M.B.

Second Professional Examination.-A. Curry, C. Daniell, E. Evans, P. Ferguson. J. Gaffney, P. Farrington, M. J. Hawkshaw, D. J Hurley, H. Kay, T. J. Lyons, P. Maguire, K. A. P. R. Murray, P. V. O'Hagan, E. Ryan, B. Wallace, A. H. T. Warnock, J. P. Zeederberg. The following candidates were approved at the autump Third Profes ional Examination:

. Blake, H. Burbidge, C. M. Burton, G. H. Caldwell, H. C. Carden, P. J. Cusack. J. D. Alton. P. G. M. Elvery, E. H. F. Gilligan, J. B Hanafin, R. B. Herrick, E. M. Loughnan, F. J. Morris, J. Molyneux O'Farrell, H. J. Raverty, T. Sheehy, and R. Stephens.

ROYAL COLLEGE OF SURGEONS OF EDINBURGH.

THE following gentlemen, having passed the requisite examinations,

were admitted Diplomates in Public Health

H. S. Ballantyne, M.B., C.M.; L. F. Bianchi, M.R.C.P.E. ; J. Jardine, M.B., Ch.B.; P. A. Harry, M.B.. Ch.B.; R. C. Monnington, M.B., Ch.B.; R. A.L van Someren, M.B., Ch.B.; K. A. Moody-Stuart, M.B., J. W.' Sutton, L.R.C.P.and S.E.; D. C. Williams, F.R.C.S.E.; R. A Cunningham, M.B., Ch.B.; A. J. MacGregor, M.D. ; and G. Wight, M.B., Ch.B.

At the same sederunt the following passed the First Examination in Public Health :

W. H. Simpson, M.B., Ch.B.; D. R. Dobie, M.D. ; J. D. Munsiff, L.R.C.P. and S.E.; and F. E. Larkins, M.B., Ch.B.

The following gentlemen, having passed the requisite examinations,

were admitted Fellows on October 18 th

N. Burnett, P. S. Clarke, H. Clifford, I. Dawson, E. Down, H. N. Fletcher, T. A. Green, R. J. E. Hanson. C. W. Harty, E. J. Hynes,
W. Kelty, G. Lyon, P. F. McFarlan, T. Myles, L. 'T. Price. T. W. E. Ross, T. W. Scott, H. N. A. Taylor, B. P. Watson, E. C. Williams, and T. J. Wright.

Election of President

Charles Watson MacGillivray, M.D., F.R.C.S.F., has been elected President of the Royal College of Surgeons of Edinburgh, in room of Sir Patrick Heron Watson, whose term of
Dr. MacGillivray is a nephew of Sir Patrick.

SOCIETY OF APOTHECARIES OF LONDON

THE following vandidates have been approved in the subjects indicated * C. H. Powell, *E. W. T. Watts, * P. C. West.

Medicine $-\uparrow$ G. N. Biggs, *W. G. H. Cable, ${ }^{*}+$ M. O. Dollie, ${ }^{*}+P$. L. Vawdrey.

idwifery.--R. C. T. Evans, F. J. Macphail, J. L. Meynell, F. B. O'Dowd, C. S. Spencer, J. M. Wilson.

The diploma of the Society was granted to Messrs. G. N. Biggs, P. L.

Vawdrey, E. W. T. Watts, P. C. West, and J. M. Wilson. * Section I. t Section II.

Erratum.-The name of Mr. F. W. Goyder, of St. John's College, upon whom the degree of M.B. was conferred at Cambridge on October 12 th, is as now printed, and not as vublished in the BRITISH. MEdICAL JOURNAL of October 2 st.

\section{MEDICO-LEGAL AND MEDICO-ETHICAL.}

THE DUTIES OF A SUBSTITUTE

Credulity writes that a patient who met with an accident to her finger, on finding that he was not at home, went to Dr. B., and told him that she was one of our correspondent's patients, but as he was not at home she had come to him. Our correspondent asks whether B. should take charge of the patient and treat the injury to the end, or should send her back with

*** Unquestionably the latter course is the right one, supposing all the circumstances to have been correctly stated, and that the patient did not wish $B$. to continue to treat the case to the end. A practitioner who sees a case as a substitute for a colleague during his illness or absence from home should scrupulously regard himself merely as taking his place, and should refuse to become the regular medical attendant of any patient so fortuitously introduced to him. If the patient insists upon the treatment so begun being completed, he should explain that he considers himself as acting throughout as a substitute for his colleague, to whom he should send a note of his attendances. The regular medical attendant may, of course, if he likes, waive any claim to the fees thus earned, but it is better that he should collect them and pay his substitute.

RELATIONS WITH CHEMISTS.

"FEMOR" says he is anxious to open a branch surgery in a poor neighbourhood, and has made arrangements with a chemist to do his dispensing, but is unable to find any suitable premises in the district except a room behind the chemist's shop. He wishes to know whether he may put up a plate on the chemist's premises without infringing any rule or regulation of the General Medical Cou

** The proposed arrangement is certainly not one which can be considered desirable, and may give rise to complaint on the part of other practitioners in the neighbourhood. We know of no pronouncement of the General Medical Council, or of any of the corporations, forbidding such an arrangement.
CONTRACTS NOT TO PRACTISE.

"DONEI M" asks whether a condition in a bond required of an assistant not to practise in that neighbourhood for ten years is unfair,

** The term of four years in a bond is usually quite sufficient to protect a principal from unscrupulous"action on the part of an assistant. but if a longer period is insisted on, it can hardly be considered unfair.

PROFESSIONAL CRUXES.

I. Cama Brito writes that, as medical attendant (paid entirely by the firm) to the employés of a large firm, he discovered that an employé, aged 15, was pregnant. He declined to inform her forewoman of his opinion, but sent for the patient's mother, and told her what he believed to be her daughter's condition; then, with the mother's consent and in her presence. questioned the patient. She made a statement incriminating her hrother, aged 17 , and his subsequent conduct seemed to confirm the girl's statement. He asks: (r) Does the fact that the firm, and not the employés, pay t

** Our answer is, Certainly not. It is the patient's secret, which her medical attendant has no right to reveal without her consent, unless. compelled to do so in a court of justice.

(2) Was the course adopted the correct one

** Quite ; the patient being a minor and having a mother, all respon. sibility for further action being taken was thus thrown upon her uatural guardian.

(3) Is it incumbent upon the medical man in such cases to inform the police?

** By no means; he is not bound to act as a private detective, snd the fact that the parents in this case tried to shelter their son and daughter, and the police only obtained information from the Board of Guardians, who subsequently took charge of the patient, does not in the least alter our opinion.

II. Our correspondent was called in early one morning to see a young man, a complete strayger, who had a bullet in his brain. The surgeon who subsequently saw him with "Caer Brito" agreed that it was no part of their duty to inform the police, thereby exposing the patient to harassing legal inquiries. After the operation the patient informed at the time that this might be untrue, and that he was ondeavouring to at the time that this might be untrue, and that he was endeavouring to consult a solicitor, and he thought no useful purpose could be served by informing the police; so the matter dropped.

*** We are of opinion that in this case also the correct course was taken.

III. An aged medical man, stranded in a large city, is approached by a medical electrician, claiming to be an M.D. of New York, who has recently opened an institute in that city, with a view to his becoming his assistant to diagnose his cases. Does the medical man lay himseli open to the charge of "covering" or of "infamous conduct

** Undoubtediy he dues; and it makes no difference whether the electrician advertise himself by laudatory puffs in the local papers, or by the distribution of handbills or pamphlets, so far as the question of "covering" is concerned, which in itself constitutes "infamous conduct," and renders him liable to be struck off the Register.

MEDICAL ETIQUETTE AT POLICE STATIONS.

ETIQUETTE writes: (I) A man is arrested for drunkenness on licensed premises and taken to police station. A., a medical man, is asked to see him, and does so. After examination A. gives a certificate stating, "Suffering from effects of alcohol." The police are not satisfied with this, so send for B., another medical man, who gives a certificate "Drunk and incapable." Is it professional etiquette for B. to give this sulting A. ? (2) A man is arrested for drunkenness and taken to a police station A. After being charged he demands a doctor, and pays him his fee for an opinion which hnppens to be unfavourable-namely, "Drunk." The man not being satisfied, asks for another doctor, who comes an hour afterwards, and although he sees the first doctor's certificate, pronounces him sober. Waa the second doctor acting professionally without consultation with the first doctor

** (x) The police recognize only two conditions, "drunk" or " sober," and police work could not be carried on if consultations were to be insisted on. (2) This second case illustrates what we have said above as to the difficulty of holding consultations in police stations. The prisoner would certainly have refused to pay a fee to the doctor who had pronounced him drunk.

\section{NOISE.}

A RECENT appeal case decided by the Supreme Court of Massachusetts was quoted on $p$. Ic63 of the Pritisn MEDICAL JOURNAL. From time to Was quoted on p. Ic63 of the PAITISB MEDICAL JOURNAL. From time to restrain noisy people who, by the persistent and unnecessary disturbance restrain noisy people who, by the persistent and unnecessary disturbance quiet-loving neighbours who, personally. may have remonstrated in vain. It is to be expected that medical practitioners would be among those who. It is to be expected that medical practitioners would be among those who
need the assistance of the law in this particular. There are two per-
tinent decisions given in recent years, both in favour of the medical applicants, who in each case had been unable, after reasonable requests, to secure the silence necessary for suecessful auscultation. In rgoo Mr. Justice Farwell, in Conry $v$ Fox, forbade a fried-fish vendor to advertise his wares by excessive shouting; it has lately been held, however, that the smell arising from the exercise of this trade is not a common-law nuisance. The other case-Sturges $v$. Bridgman - was one in which a medical man objected to the cuntinual noise made by a ne
confectioner who used a pestle and mortar for trade purposes. 